\title{
In vivo assessment of cyto/genotoxic, antigenotoxic and antifungal potential of Costus spiralis (Jacq.) Roscoe leaves and stems
}

\author{
WENDEL C. DE SOUSA ${ }^{1}$, ANDRESSA T.S. PAZ ${ }^{2}$, JAMIRA D. ROCHA ${ }^{1}$, EDEMILSON C. DA CONCEIÇÃ ${ }^{2}$, \\ LUCIANE M. DE ALMEIDA ${ }^{3}$, LEE C. CHEN ${ }^{4}$, LEONARDO L. BORGES ${ }^{3,5}$ and ELISA F.L.C. BAILÃO ${ }^{3}$ \\ ${ }^{1}$ Universidade Estadual de Goiás, Câmpus Iporá, Av. R2, Qd.01, Jardim Novo Horizonte II, 76200-000 Iporá, GO, Brazil \\ ${ }^{2}$ Laboratório de Pesquisa, Desenvolvimento \& Inovação de Bioprodutos, Faculdade de Farmácia, \\ Universidade Federal de Goiás, Rua 240, Setor Leste Universitário, 74605-170 Goiânia, GO, Brazil \\ ${ }^{3}$ Laboratório de Biotecnologia, Universidade Estadual de Goiás, Câmpus Henrique Santillo, BR \\ 153, no 3.105, Fazenda Barreiro do Meio, 75132-903 Anápolis, GO, Brazil \\ ${ }^{4}$ Departamento de Biologia Geral, Instituto de Ciências Biológicas I, Universidade Federal de \\ Goiás, Câmpus Samambaia, Av. Esperança, s/n, 74690-900 Goiânia, GO, Brazil \\ ${ }^{5}$ Escola de Ciências Médicas, Farmacêuticas e Biomédicas, Pontifícia Universidade Católica de \\ Goiás, Av. Universitária, 1440, Setor Universitário, 74605-010 Goiânia, GO, Brazil
}

Manuscript received on October 2, 2017; accepted for publication on December 8, 2017

\begin{abstract}
Costus spiralis is a Brazilian native plant used in popular medicine, but the safety of this therapeutic use needs investigation. So, the aim of this study was to evaluate the cytogenotoxic and antigenotoxic effects of C. spiralis leaves or stems aqueous extracts on Allium cepa root cells. Moreover, a phytochemical screening and an antioxidant and antifungal activities evaluation were performed. C. spiralis aqueous extracts presented cytotoxicity, but no mutagenicity was observed. When the antigenotoxicity was evaluated, C. spiralis leaves aqueous extract presented preventive and modulatory effects on A. cepa root cells, reducing the sodium azide cytogenotoxic effects. In contrast, $C$. spiralis stems aqueous extract enhanced the sodium azide cytogenotoxicity in some conditions. The phytochemical screening revealed the presence of phenolic compounds in C. spiralis. When total phenolic content was determined, the leaves presented $73 \%$ more phenolic content than stems. Corroborating this data, C. spiralis leaves antioxidant potential was $30 \%$ higher than C. spiralis stems. However, these extracts did not present antifungal activity against Candida spp. In conclusion, empirical utilization of $C$. spiralis aqueous extracts should be avoided. Moreover, the cytotoxic effect of $C$. spiralis leaves and stems can play an important role in anticancer therapy and must be deeply studied.
\end{abstract}

Key words: Allium cepa test, antioxidant, medicinal plant, secondary metabolites.

\section{INTRODUCTION}

Costus spiralis (Jacq.) Roscoe, popular known as cana-de-macaco or cana-do-brejo, is a Brazilian

Correspondence to: Elisa Flávia Luiz Cardoso Bailão

E-mail: elisaflavia@gmail.com native plant found in Cerrado, Amazon, Atlantic Forest and Caatinga biomes (Maas and Maas 2015). This species is a member of Costaceae family which is commonly used in popular medicine to treat urinary infections and kidney stones (Pilla et al. 2006). The leaves infusion is used to treat 
arterial hypertension and as diuretic and the leaves decoction is used against diarrhea. Stems infusion is used to treat hepatitis and abdominal pain. Topically, the plant is used to treat syphilis wounds and tumors (Di Stasi and Hiruma-Lima 2002).

Besides the use of $C$. spiralis by the population, there is also some information about its therapeutic potential on the literature. For example, the antiurolithiatic activity of $C$. spiralis aqueous extract significantly reduced the growth of calcium oxalate calculi in the urinary bladder of rats (Viel et al. 1999), which is in agreement with its traditional use. It was also demonstrated that the $C$. spiralis leaves aqueous fraction reduces mammalian myocardium contractility by impairing the calcium inward current in this muscle. This data support the use of C. spiralis in arterial hypertension or cardiac arrhythmias treatment (Britto et al. 2011). The antioxidant activity of dichloromethane and methanol extracts of $C$. spiralis rhizome and root was also demonstrated. Only the dichloromethane extract presented antibacterial activity in this work (Habsah et al. 2000). In accordance, C. spiralis leaves aqueous extract presented antimicrobial activity against different Vibrio cholerae strains (Pérez et al. 2008). Steroidal saponins isolated from C. spiralis fresh rhizomes inhibited the increase in vascular permeability caused by acetic acid, a typical model of first stage inflammatory reaction, suggesting an anti-inflammatory activity (Silva and Parente 2004).

All those therapeutic activities observed in $C$. spiralis extracts can be intrinsically related to the secondary metabolites produced by this plant. It is known that the methanolic extract of $C$. spiralis leaves presents flavonoids, sterols and alkaloids (Braga et al. 2007). The aqueous fraction instead presents phenols, tannins, flavones, xanthones, flavonoids, flavonols, flavononols, flavonones, and saponins (Britto et al. 2011). Saponins and flavonol glycosides were isolated from $C$. spiralis rhizome and leaves, respectively (Antunes et al. 2000,
Silva and Parente 2004). All those compounds are able to increase the plant survival, since they can present antimicrobial, antiviral and antigerminative activities (Gobbo-Neto and Lopes 2007). The secondary metabolites can also be used to improve human health, preventing mutagenic, cytotoxic and genotoxic effects (Sun et al. 2015). On the other hand, these substances could induce genotoxic alterations, what could cause different pathologies, such as cancer (Sakihama et al. 2002).

Most plants with therapeutic activities were not sufficiently studied regarding to cytogenotoxic/ mutagenic actions, and these parameters are important to ensure the safety of therapeutic use (Tedesco et al. 2015). The Allium cepa L. test system is widely used for evaluating the cytogenotoxic potential of infusions made with medicinal plants (Bagatini et al. 2007). Some studies point to a high concordance between this vegetal and mammal systems (Bagatini et al., 2007, Sturbelle et al. 2010, Fedel-Miyasato et al. 2014, Roberto et al. 2016). Besides that, it is a low cost and easyhandling assay (Leme and Marin-Morales 2009), which allow to expose the test organism directly to complex mixtures without previous treatment of the test sample (Rank and Nielsen 1993). The present study aimed to evaluate the cytogenotoxic and antigenotoxic effects of crude aqueous extracts of $C$. spiralis leaves or stems on the cell cycle of $A$. cepa roots at different concentrations and exposure protocols. Moreover, the phytochemical screening and antioxidant and antifungal activities evaluation of these extracts were performed.

\section{MATERIALS AND METHODS}

\section{PLANT MATERIAL}

C. spiralis leaves were collected from Israelândia in Goiás State (16¹9'21.3”S 5054’20.0”W, 383 m), Brazil, in August 2013. The plant was identified by Dr. Aristônio Magalhães Teles, a taxonomist from Universidade Federal de Goiás, Brazil. A voucher 
specimen was deposited at the Herbarium of the Universidade Estadual de Goiás (9208). C. spiralis leaves and stems were dried at room temperature and powdered in a knife mill. The powdered material was stored from light and moisture was used for subsequent extraction process. For this, the leaves or stems were first soaked during 10 min in sterile water and then boiled during 5 min. Three different concentrations of $C$. spiralis leaves (18 mg/ml, CsL18; $9 \mathrm{mg} / \mathrm{ml}, C s L 9$; and $4.5 \mathrm{mg} /$ $\mathrm{ml}, C s \mathrm{~L} 4.5)$ or stems $(18 \mathrm{mg} / \mathrm{ml}, C s S 18 ; 9 \mathrm{mg} / \mathrm{ml}$, CsS9; and $\left.4.5 \mathrm{mg} / \mathrm{ml}, C_{S S} 4.5\right)$ aqueous extracts were used in this work. These concentrations were chosen based on Costus spicatus popular use (Keller et al. 2009), since no scientific references for $C$. spiralis was found and based on a taxonomic proximity between these species.

\section{Allium cepa TEST}

The Allium cepa test was adapted from the method reported by (Fiskesjo 1985). Briefly, A. cepa bulbs were exposed to three different concentrations of C. spiralis leaves (CsL18, CsL9 and CsL4.5) or stems (CsS18, CsS9 and CsS4.5) aqueous extracts. Sterile mineral water and paracetamol $0.8 \mathrm{mg} / \mathrm{ml}$ or sodium azide $2 \mathrm{~g} / 1$ were used as negative (NC) and positive (PC) controls, respectively. After $24 \mathrm{~h}$ of exposure, roots were collected for microscopic evaluation. For this, 1000 cells were evaluated from each bulb, totalizing 6 bulbs per treatment (6000 cells). After $72 \mathrm{~h}$, the roots were collected for macroscopic evaluation to assess toxicity. For this, the roots were measured with a pachymeter and the following parameters were observed: changes in tissue color, bending or twisting of the roots and presence of tumors.

\section{Cytogenotoxic evaluation}

For cytogenotoxic evaluation, the roots were collected, washed with sterile mineral water and placed in Carnoy's fixative solution $(3: 1$ ethanol:glacial acetic acid v/v) refrigerated at 4 ${ }^{\circ} \mathrm{C}$ for $24 \mathrm{~h}$, followed by $70 \%$ ethanol solution and refrigeration. The roots were subsequently hydrolysed in $\mathrm{HCl} 1 \mathrm{~N}$ for $10 \mathrm{~min}$ and washed with sterile mineral water. After this, the roots were placed on a microscope slide and one drop of acetocarmine $1 \%$ was added. Then, the roots were macerated with rusty needles (Mondin and Neto 2006). A coverslip were placed on the material and a pressure was made to help separate the cells. The slides were evaluated using a Zeiss Primo Star $^{\circledR}$ optical microscope with magnification of 40 or 100x. The following parameters were observed: (a) mitotic index (MI) and the frequency of (b) chromosomal aberrations (CA), (c) micronuclei $(\mathrm{MN})$ and (d) nuclear abnormalities (NA). MI was calculated as follow:

$$
\operatorname{MI}(\%)=\frac{\text { number of cells in mitosis }}{1000} \times 100
$$

\section{Antigenotoxic evaluation}

The $A$. cepa test was also used to evaluate the antigenotoxicity of the $C$. spiralis aqueous extract. Here sodium azide $2 \mathrm{~g} / 124 \mathrm{~h}$ exposition was used as positive control (PC) because of its bigger mutagenic potential, and sterile mineral water 24 $\mathrm{h}$ exposition as negative control (NC). Three types of exposure protocols were performed: (1) pretreatment, in which the $A$. cepa bulbs were exposed initially to $C$. spiralis leaves or stems aqueous extract for $24 \mathrm{~h}$ and the roots were then washed in distilled water and placed in sodium azide solution for $24 \mathrm{~h}$; (2) co-treatment, in which the bulbs were exposed to C. spiralis leaves or stems aqueous extracts and sodium azide solution for $24 \mathrm{~h}$; and (3) post-treatment, in which the bulbs were first placed in sodium azide solution for $24 \mathrm{~h}$, and then the roots were rinsed with distilled water and exposed to $C$. spiralis leaves or stems aqueous extracts for $24 \mathrm{~h}$. The samples were then processed in the similar way as mentioned above. 


\section{STATISTICAL ANALYZES}

Data belonging to the same group (leaves or stems and pre-, co- or post-treatment) were compared with negative and positive controls using one-way ANOVA and Tukey's pairwise comparison. For this, Microsoft ${ }^{\circledR}$ Excel $^{\circledR}$ for Mac 2011 was used to calculate average and standard deviation of the data and PAST version 1.94 (Hammer et al. 2001) was used to compare the means. We considered statistically significant $\mathrm{p}$ values $<0.05$.

\section{PHYTOCHEMICAL SCREENING}

We evaluated the presence of the following secondary metabolites: alkaloids (Dragendorff Hager and Mayer reaction), anthraquinones (acid/base reaction), coumarins (under UV light observation), flavonoids (cianidin and sulfuric acid reactios, A-1 and A-II), phenolic compounds (precipitation reaction with ferric chloride), tannins (iron salts reaction, protein precipitation, B-1 and B-II), and saponins (Lieberman-Buchard reaction and foam index), using methodologies previously described (Matos 1988, Matos and Matos 1989, Costa 2001).

\section{DETERMINATION OF TOTAL PHENOLS}

For total phenols determination, aqueous extracts were prepared from $0.75 \mathrm{~g}$ of the sample (leaves or stems). This material was transferred to a 250 $\mathrm{ml}$ erlenmeyer flask and $150 \mathrm{ml}$ of distilled water were added. The mixture was heated to boiling and kept in a water bath at between 80 and $90{ }^{\circ} \mathrm{C}$ for $30 \mathrm{~min}$. After cooling, the contents of the flask were transferred to a $250 \mathrm{ml}$ volumetric flask and the volume was made up with distilled water. The flask was then left for sedimentation and the liquid was filtered through qualitative filter paper. The first $50 \mathrm{~mL}$ of filtrate was discarded. Each sample was prepared in triplicate. The aqueous extracts obtained were used for the determination of total phenols by the method of Hagerman \& Butler adapted by Waterman and Mole (1994).

\section{ANTIOXIDANT ACTIVITY (AOA)}

The scavenging activity of the DPPH free radical was performed according to the adapted method described by Sánchez-Moreno and colleagues (1998). The samples were diluted in the same solution resulting in the concentrations 9 to 1.8 $\mathrm{mg} / \mathrm{ml}$. After, $0.1 \mathrm{ml}$ of each solution was mixed with $3.9 \mathrm{ml}$ of a $60 \mu \mathrm{M}$ DPPH solution. After an incubation time of $30 \mathrm{~min}$ at room temperature, the absorbances were measured at $515 \mathrm{~nm}$ (Asample). The blank was performed with methanol without DPPH (Ablank). A control solution was performed using $3.9 \mathrm{ml}$ DPPH solution and $0.1 \mathrm{ml}$ of methanol (Acontrol). The scavenging activity of each solution was determined according to the following equation:

$$
A O A(\%)=100-\frac{(\text { Asample }- \text { Ablank }) \times 100}{\text { Acontrol }}
$$

AOA was finally expressed as $\mathrm{IC}_{50}$, which means the concentration $(\mathrm{mg} / \mathrm{ml})$ of the extract required to cause a $50 \%$ decrease in initial content of the DPPH solution. The assays were performed in triplicate.

\section{AGAR-WELL DIFFUSION ASSAY}

Two Candida species were tested in this work: Candida albicans (ATCC 28367) and Candida parapsilosis (ATCC 22019). The yeast cells were cultivated on Sabouraud dextrose agar medium (Himedia Laboratories Pvt. Ltd., India) at room temperature. Every $48 \mathrm{~h}$, the yeast cells were put in a fresh medium for maintenance. Fresh cells were used to produce an inoculum in sterile saline solution $(\mathrm{NaCl} 0.9 \%)$. The cell suspension was standardized in spectrophotometer (BEL Photonics $2000 \mathrm{UV}$ ) at $625 \mathrm{~nm}$ to $0.5 \mathrm{in} \mathrm{McFarland} \mathrm{scale.} \mathrm{The}$ antifungal activity was performed using the agarwell diffusion assay in triplicate. Briefly, Sabouraud 
dextrose agar plates with $10 \mu \mathrm{g} / \mathrm{ml}$ gentamicin were seeded with the cell suspension prepared. After this, 5 wells $6 \mathrm{~mm}$ in diameter each were made with help of a sterile tip. Each well was filled with $50 \mu 1$ of C. spiralis leaves (CsL18, CsL9 and CsL4.5) or stems aqueous extracts ( $C s \mathrm{~S} 18, C s \mathrm{~S} 9$ and $C s \mathrm{~S} 4.5)$. Fluconazole (Halex Istar Indústria Farmacêutica LTDA., Brasil) $2 \mathrm{mg} / \mathrm{ml}$ and sterile water were used as positive and negative controls, respectively. The plates were incubated at room temperature for $48 \mathrm{~h}$. Inhibition halos were measured using a pachymeter and compared with the positive and negative controls.

\section{RESULTS}

\section{CYTOGENOTOXIC EVALUATION}

C. spiralis leaves or stems aqueous extracts presented inhibitory effect on A. cepa root's growth. This inhibition seems to be concentrationdependent, since the smallest concentration from leaves or stems inhibited $A$. cepa root's growth less than the highest concentration (Fig. 1a). The roots

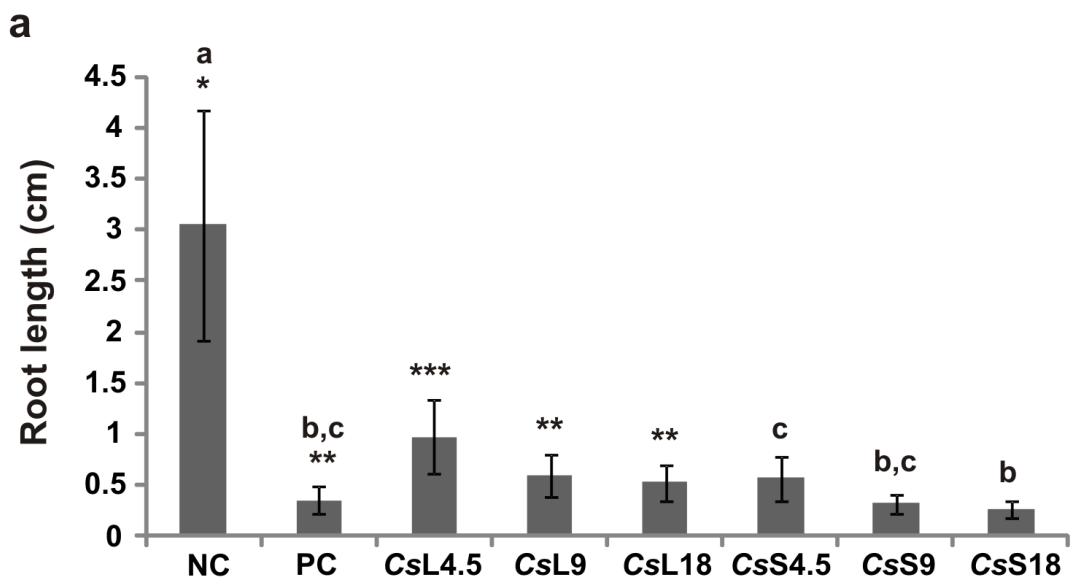

b

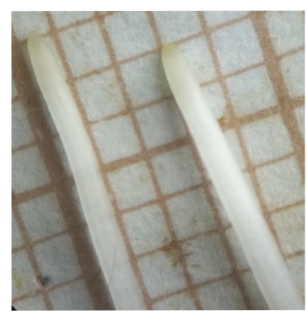

NC

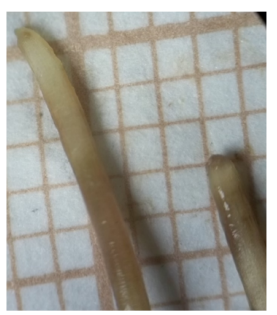

PC

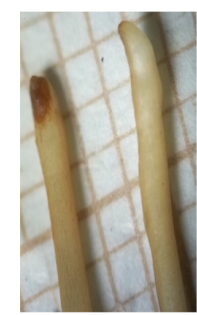

CsL

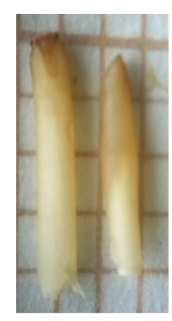

CsS

Figure 1 - Costus spiralis aqueous extracts toxicity against Allium cepa meristematic root cells. $A$. cepa bulbs were exposed to $C$. spiralis leaves or stems aqueous extracts for $72 \mathrm{~h}$. After this time, the root's growth was evaluated. The mean and standard deviation of $A$. cepa root length after $C$. spiralis extracts exposure are presented (a). A representative image of treatments is also exhibited, showing changes in color, necrosis marks, bending and tumors (b). NC: negative control; PC: positive control; CsL4.5: 4.5 $\mathrm{mg} / \mathrm{ml}$ leaves aqueous extracts; $C s \mathrm{~L} 9: 9 \mathrm{mg} / \mathrm{ml}$ leaves aqueous extracts; $C s \mathrm{~L} 18: 18 \mathrm{mg} /$ $\mathrm{ml}$ leaves aqueous extracts; $C s S 4.5: 4.5 \mathrm{mg} / \mathrm{ml}$ stems aqueous extracts; $C s S 9: 9 \mathrm{mg}$ / $\mathrm{ml}$ stems aqueous extracts; and CsS18: $18 \mathrm{mg} / \mathrm{ml}$ stems aqueous extracts. Bars with different number of asterisks or letters represent statistically significant differences $(\mathrm{p}<$ 0.05 ) between leaves or stems treatments, respectively, and controls. 


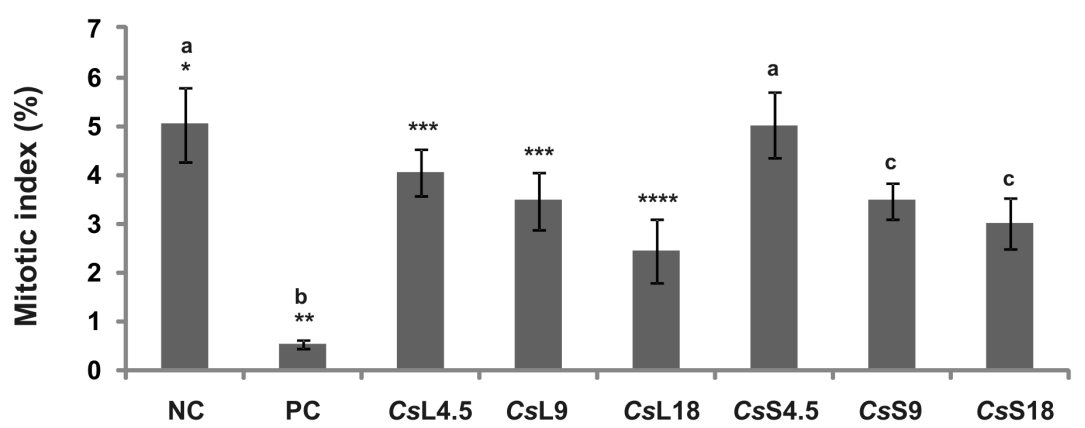

Figure 2 - Cytotoxic effects of Costus spiralis aqueous extracts against Allium cepa meristematic root cells. After $24 \mathrm{~h}$ exposure to $C$. spiralis leaves or stems aqueous extracts, $A$. cepa root cells were microscopically evaluated, considering interphase cells $\mathrm{x}$ cells in mitotic division. The graphic represents the mean percentage and standard deviation of the mitotic index. NC: negative control; PC: positive control; CsL4.5: 4.5 $\mathrm{mg} / \mathrm{ml}$ leaves aqueous extracts; $C s \mathrm{~L} 9: 9 \mathrm{mg} / \mathrm{ml}$ leaves aqueous extracts; $C s \mathrm{~L} 18: 18 \mathrm{mg} /$ $\mathrm{ml}$ leaves aqueous extracts; $C s \mathrm{~S} 4.5: 4.5 \mathrm{mg} / \mathrm{ml}$ stems aqueous extracts; $C s S 9: 9 \mathrm{mg}$ / $\mathrm{ml}$ stems aqueous extracts; and CsS18: $18 \mathrm{mg} / \mathrm{ml}$ stems aqueous extracts. Bars with different number of asterisks or letters represent statistically significant differences ( $\mathrm{p}<$ 0.05 ) between leaves or stems treatments, respectively, and controls.

presented changes in color, necrosis marks, bending and tumors when treated with these extracts (Fig. 1b), indicating toxicity of $C$. spiralis extracts.

Corroborating the macroscopic data, the microscopic analysis revealed a statistically significant reduction on the MI of the organisms treated with $C$. spiralis leaves or stems aqueous extracts when compared to the negative control (Fig. 2). It indicates a cytotoxic effect of the concentrations of $C$. spiralis extracts used in this work, with exception of $C s S 4.5$. In regard to $C$. spiralis leaves aqueous extract, the MI inhibition seems to be concentration-dependent (Fig. 2). On the other hand, $C$. spiralis extracts did not induce CA or MN mutagenicity in A. cepa root meristems. Only $0.081 \%$ of analyzed cells presented a genotoxic alteration, indicating no genotoxic or mutagenic activity of the tested extracts.

\section{ANTIGENOTOXIC EVALUATION}

When $A$. серa root meristems were initially exposed to $C$. spiralis leaves or stems aqueous extracts in pretreatment and were posteriorly treated with sodium azide solution, C. spiralis leaves aqueous extract was able to prevent the cytotoxicity and mutagenicity of the sodium azide (Fig. 3a and Fig. 4a). The cytotoxic prevention of $C$. spiralis leaves aqueous extract seems to be concentration-dependent. However, C. spiralis stems aqueous extract not only failed to prevent the sodium azide cytotoxicity, but also enhanced this cytotoxicity in a concentration-dependent manner (Fig. 3b). Regarding MN frequency, the highest concentration of $C$. spiralis stems aqueous extract $(C s \mathrm{~S} 18)$ also enhanced the sodium azide mutagenicity. In contrast, the other concentrations of $C$. spiralis stems aqueous extract used in this work ( $C s \mathrm{~S} 4.5$ and $C s \mathrm{~S} 9)$ prevented the sodium azide mutagenicity (Fig. 4b).

In co-treatment, $C$. spiralis leaves aqueous extract modulated the cytotoxicity and mutagenicity of sodium azide in a concentration-independent manner, increasing the root meristem cell multiplication and decreasing the $\mathrm{MN}$ frequency, respectively, when compared to the positive control (Fig. 3a and Fig. 4a). In regard to $C$. spiralis stems aqueous extract, we could not observe a significant modulation of sodium azide cytotoxicity and mutagenicity, with exception of the highest 
a

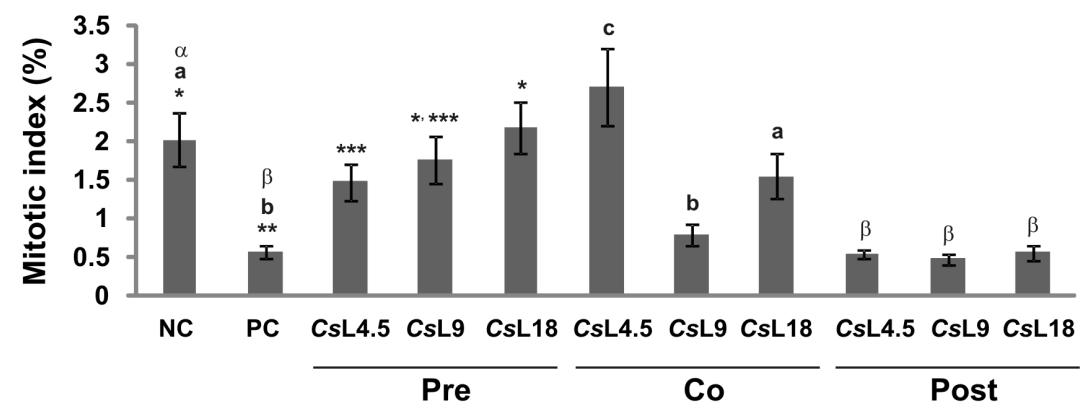

b

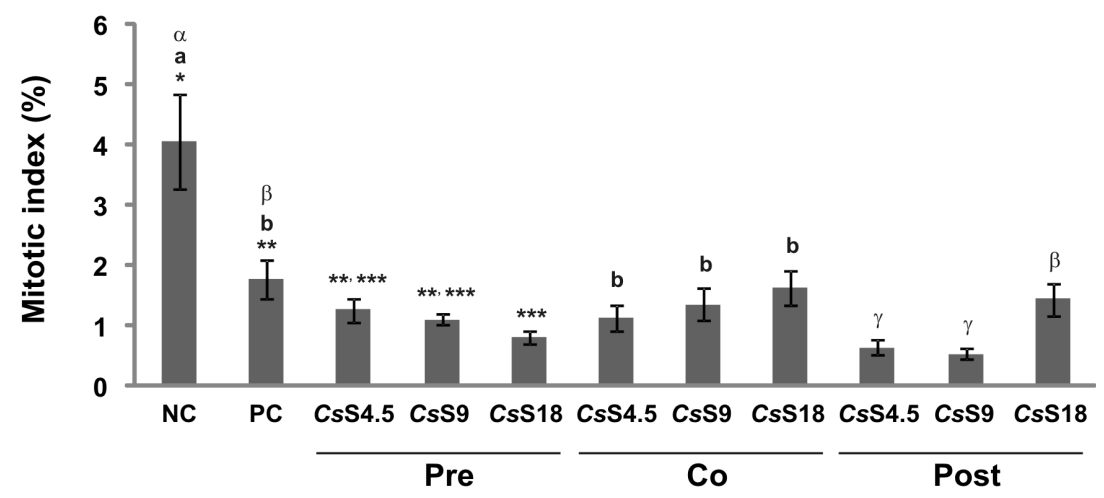

Figure 3 - Anticytotoxic effects of Costus spiralis aqueous extracts against Allium cepa meristematic root cells. The anticytotoxic evaluation was performed using sodium azide as positive control in three different exposure protocols: pre-treatment, cotreatment and post-treatment with $C$. spiralis leaves (a) or stems (b) aqueous extracts. The data is represented as mean percentage and standard deviation of the mitotic index. $\mathrm{NC}$ : negative control; PC: positive control; $C s \mathrm{~L} 4.5: 4.5 \mathrm{mg} / \mathrm{ml}$ leaves aqueous extracts; CsL9: $9 \mathrm{mg} / \mathrm{ml}$ leaves aqueous extracts; $C s \mathrm{~L} 18: 18 \mathrm{mg} / \mathrm{ml}$ leaves aqueous extracts; CsS4.5: $4.5 \mathrm{mg} / \mathrm{ml}$ stems aqueous extracts; $C s \mathrm{~S} 9: 9 \mathrm{mg} / \mathrm{ml}$ stems aqueous extracts; and $C s S 18: 18 \mathrm{mg} / \mathrm{ml}$ stems aqueous extracts. Bars with different number of asterisks or roman letters or greek letters represent statistically significant differences $(p<0.05)$ between leaves (a) or stems (b) treatments and controls in pre-, co- or post-treatment, respectively.

concentration (CsS18) that enhanced the sodium azide mutagenicity (Fig. 3b and Fig. 4b).

In post-treatment, $C$. spiralis aqueous extracts failed to inhibit the cytotoxic activity of sodium azide (Fig. 3). Contrariwise, the lower concentrations of $C$. spiralis stems aqueous extract (CsS4.5 and CsS9) also enhanced the sodium azide cytotoxicity (Fig. 3b). Regarding MN frequency, C. spiralis leaves aqueous extracts enhanced the mutagenicity potential of sodium azide (Fig. 4a). While just the lower concentration of $C$. spiralis stems aqueous extract ( $C s \mathrm{~S} 4.5)$ enhanced the sodium azide mutagenicity (Fig. 4 b).

Some other cellular alterations, like necrosis, CA and NA were also observed (Fig. 5), but their frequency was not relevant in this work.

\section{PHYTOCHEMICAL SCREENING AND PHENOL QUANTIFICATION}

The phytochemical screening of $C$. spiralis leaves and stems revealed the presence of phenolic compounds, flavonols, flavanones, flavones, 
a

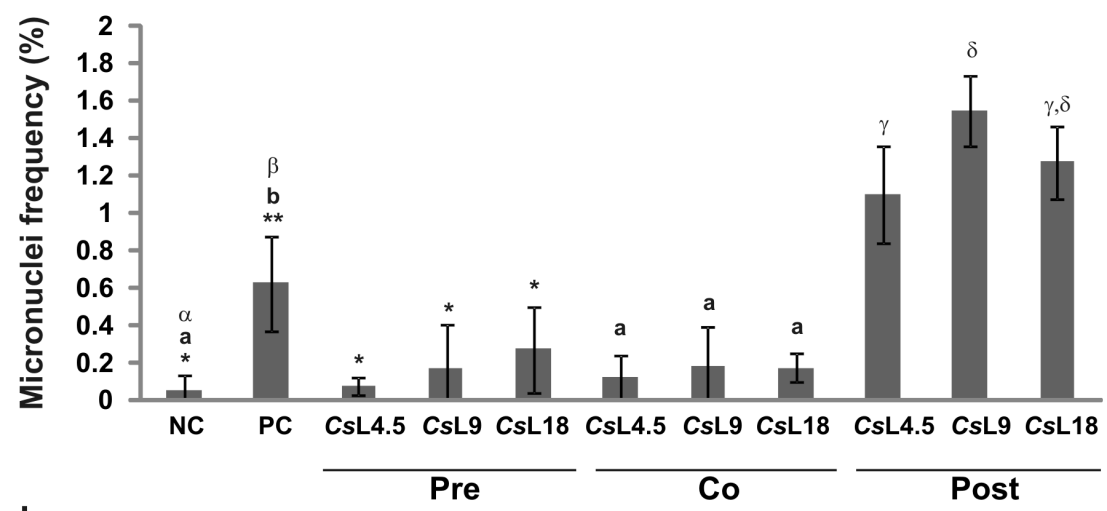

b

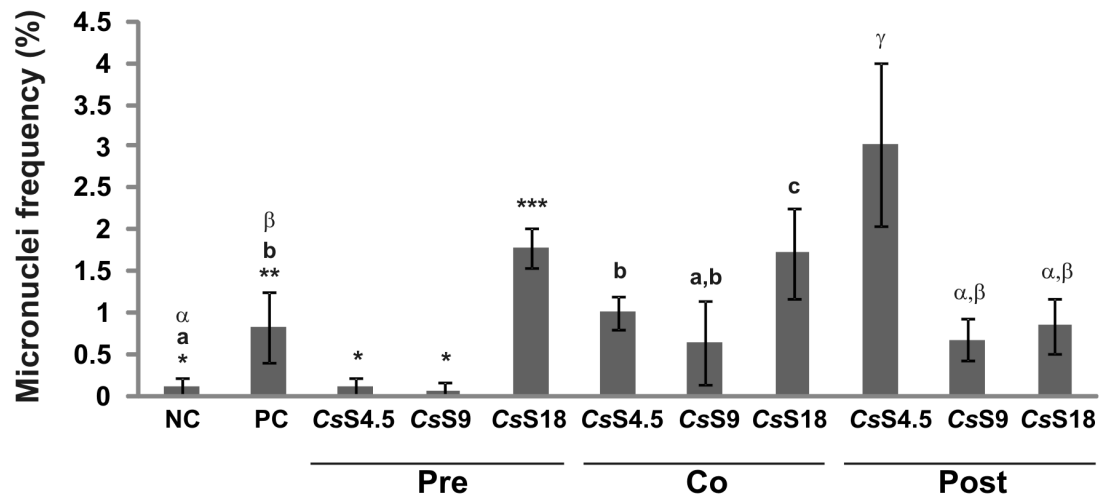

Figure 4 - Micronuclei frequency on Allium cepa meristematic root cells exposed to Costus spiralis leaves or stems aqueous extracts. This evaluation was performed using sodium azide as positive control in three different conditions: pre-treatment, cotreatment and post-treatment with C. spiralis leaves (a) or stems (b) aqueous extracts. The data is represented as mean percentage and standard deviation of micronucleus frequency. NC: negative control; PC: positive control; CsL4.5: $4.5 \mathrm{mg} / \mathrm{ml}$ leaves aqueous extracts; CsL9: $9 \mathrm{mg} / \mathrm{ml}$ leaves aqueous extracts; $C s L 18: 18 \mathrm{mg} / \mathrm{ml}$ leaves aqueous extracts; $C S S 4.5: 4.5 \mathrm{mg} / \mathrm{ml}$ stems aqueous extracts; $C S S 9: 9 \mathrm{mg} / \mathrm{ml}$ stems aqueous extracts; and $C_{S} S 18: 18 \mathrm{mg} / \mathrm{ml}$ stems aqueous extracts. Bars with different number of asterisks or roman letters or greek letters represent statistically significant differences ( $p<0.05)$ between leaves (a) or stems (b) treatments and controls in pre-, co- or post-treatment, respectively.

tannins and saponins (Table I). The total phenolic content was determined, indicating $1.23 \%$ and $0.71 \%$ in C. spiralis leaves and stems, respectively.

\section{ANTIOXIDANT EVALUATION}

Considering the high amount of phenolic compounds present in C. spiralis leaves and stems, we decided to investigate the antioxidant potential of this plant. Using DPPH radical scavenging method, we observed a $\mathrm{IC}_{50}=11.82 \mathrm{mg} / \mathrm{ml}$ to leaves and $\mathrm{IC}_{50}=15.38 \mathrm{mg} / \mathrm{ml}$ to stems, comparing with tannic acid $\mathrm{IC}_{50}$ of $0.88 \mathrm{mg} / \mathrm{ml}$. This result suggests that the antioxidant potential of $C$. spiralis leaves is $30 \%$ higher than $C$. spiralis stems.

\section{ANTIFUNGAL EVALUATION}

Observing the $C$. spiralis cytotoxic potential, we decide to evaluate the antifungal activity of $C$. 


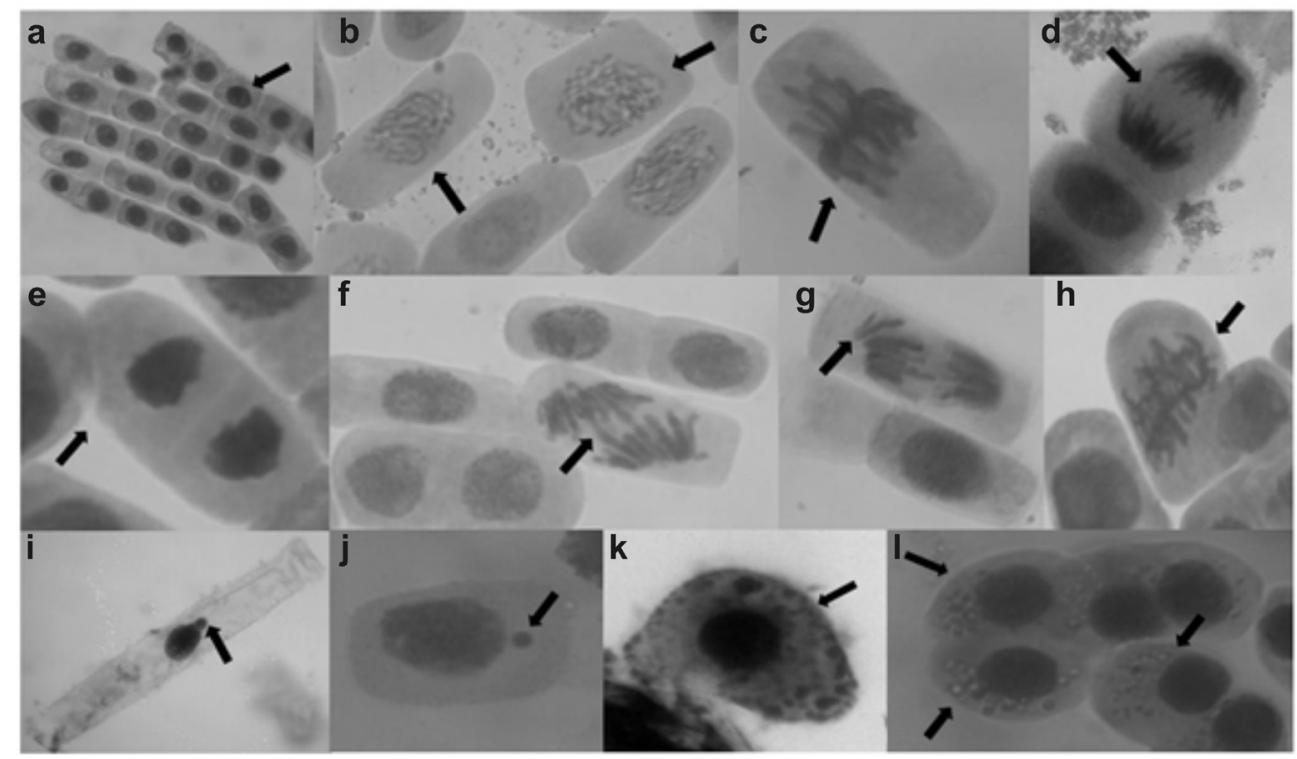

Figure 5 - Meristematic root cells in different mitosis phases and abnormalities probably induced by Costus spiralis leaves or stems exposure. Normal cells in interphase (a), prophase (b, arrow), metaphase (c, arrow), anaphase (d, arrow) and telophase (e, arrow). Chromosomal aberrations, like chromosome bridges (f, arrow), chromosome losses (g, arrow) and chromosome adherence (h, arrow) were observed. Nuclear abnormalities, like nuclear bud (i, arrow), micronuclei (j, arrow) and cellular alterations, like apoptotic cells (k, arrow) and cells in necrosis (l, arrow) were also observed in this work.

TABLE I

Investigation of secondary metabolites classes in Costus spiralis leaves or stems.

\begin{tabular}{ccc}
\hline Secondary metabolites & Leaves & Stems \\
\hline Phenolic compounds & + & + \\
Flavonols, Flavanones & + & + \\
Flavones (cyanidin) & + & + \\
Tannins & + & + \\
Coumarins & - & - \\
Alkaloids & - & - \\
Anthraquinones & - & - \\
Saponins & + & + \\
\hline
\end{tabular}

+ presence.

- absence.

spiralis leaves or stems aqueous extracts. The concentrations of $C$. spiralis extracts used in this work showed no inhibitory activity against $C$. albicans or C. parapsilosis, when compared with the fluconazole positive control. The fluconazole inhibition zone diameter was $1.6 \mathrm{~cm} \pm 0.15$ and 1.4 $\mathrm{cm} \pm 0.23$ against $C$. albicans and C. parapsilosis, respectively (Fig. 6).

\section{DISCUSSION}

The use of herbal medicinal products and supplements has increased over the past three decades. In developed countries, herbal therapy is used with the expectation that it will promote healthier living. In developing countries, herbal medicine is an integral part of the culture of communities because synthetic drugs are imported, have high costs, and thus are inaccessible to majority of the population (Bailão et al. 2015). However, most of them were not deeply studied regarding the safe use by population. Some species could present cytotoxic or mutagenic substances in their composition that could be harmful to humans (Bagatini et al. 2007). In this study, the cytogenotoxic potential of $C$. spiralis leaves or stems aqueous extracts was investigated. Using $A$. cepa bioassay, both $C$. spiralis leaves and stems aqueous extracts seems to present concentrationdependent cytotoxic effects. However no genotoxic 

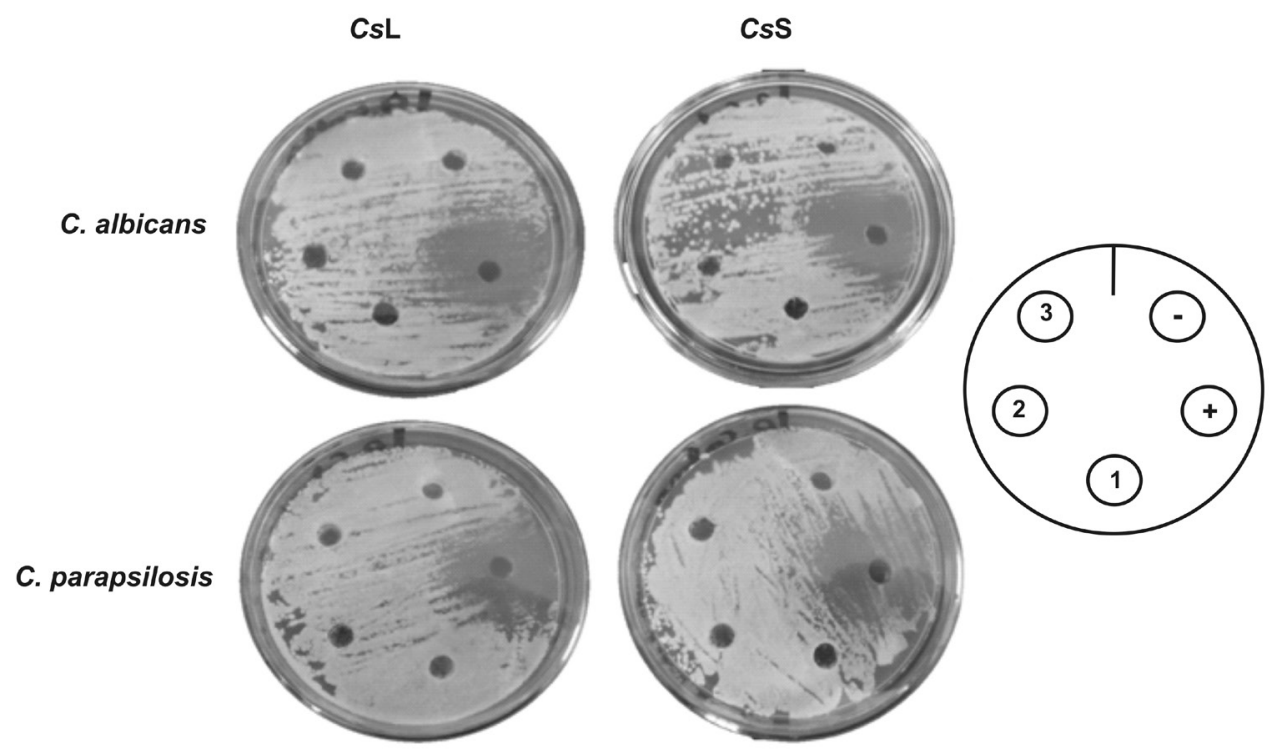

Figure 6 - Costus spiralis leaves or stems aqueous extract presented no antifungal activity against Candida spp. C. albicans and C. parapsilosis were cultivated on Sabouraud Dextrose agar for $48 \mathrm{~h}$. Then, the yeasts were spreaded on this media in presence of three different concentrations of $C$. spiralis leaves $(\boldsymbol{C} \mathbf{s} \mathbf{L})$ or stems $(\boldsymbol{C} \boldsymbol{S} \mathbf{S})$ aqueous extract: $18 \mathrm{mg} / \mathrm{ml}(\mathbf{1}), 9 \mathrm{mg} / \mathrm{ml} \mathrm{(2)} \mathrm{or} 4.5 \mathrm{mg} / \mathrm{ml}(\mathbf{3})$. After $48 \mathrm{~h}$, the zones of inhibition were measured using a ruler. Fluconazol and distilled water were used as positive (+) and negative (-) control, respectively.

effect was observed in the concentrations tested in this work, based on this in vivo vegetal test system. The reduction of mitotic activity of $A$. cepa meristematic cells in presence of $C$. spiralis aqueous extracts may be due to inhibition of DNA synthesis or a blocking of cells in G2 phase as a result of damage in DNA (Sudhakar et al. 2001). Maybe because of G2 phase arrest, we could not observe a high amount of CA and NA in presence of C. spiralis aqueous extracts. Delay in DNA damage checkpoints provides time for the damaged DNA to be repaired, after which the cell-cycle brakes are released and progress resumes (Hartwell and Weinert 1989).

Similarly to what was observed in this work, Solidago microglossa DC. (Asteraceae) leaves infusion presented cytotoxic but not mutagenic effect using A. cepa test. S. microglossa is a vegetal species which contains tannins and flavonoids, among other substances, in its chemical composition (Bagatini et al. 2009). Tannins act in protein precipitation and enzymatic inhibition. So, the enzymatic interference assigned to tannins may be responsible for the inhibition of $A$. серa meristematic cell division observed both in this work and in S. microglossa study (Teixeira et al. 2003, Bagatini et al. 2009). Some phenolic compounds, such as flavonoids, act as prooxidant mainly in systems that contain redox-active metals, which in presence of $\mathrm{O}_{2}$ may led to ROS and phenoxyl radicals formation, which damage DNA and other biomolecules (Shi et al. 2001, Galati and O'Brien 2004). So, the presence of these secondary metabolites could also contribute to $C$. spiralis cytotoxic activity against $A$. cepa meristematic cells. Corroborating this hypothesis, a phytochemical screening performed in this work revealed the presence of phenolic compounds, flavonols, flavanones, flavones, tannins and saponins in both $C$. spiralis leaves and stems. 
When the antigenotoxicity was evaluated, we observed that the $C$. spiralis leaves aqueous extract presents a preventive and a modulatory effect on A. cepa root cells in presence of sodium azide and this extract was able to reduce the sodium azide mutagenic effect. However, this extract was not able to activate the repair system to correct mistakes on cell cycle promoted by the sodium azide and then enhanced sodium azide mutagenicity on posttreatment. Regarding the $C$. spiralis stems aqueous extract, we observed that this extract enhanced the sodium azide cytotoxicity and mutagenicity in some conditions.

These results suggest a dual-role to $C$. spiralis leaves aqueous extract, reducing sodium azide damage effects in some situations (pre- and co-treatment) or enhancing the sodium azide mutagenicity in others (post-treatment). Sodium azide is an inhibitor of catalase, peroxidase and cytochrome oxidase, thus influencing respiratory processes, increasing the oxygen free radicals and reducing the efficiency of DNA repair (Gruszka et al. 2012). Since sodium azide reduce the DNA repair efficiency, some phenolic compounds present in the C. spiralis leaves aqueous extract could be acting, during post-treatment, as a pro-oxidant or binding directly to DNA, promoting unrepaired clastogenic events what could induce micronuclei formation (Ferguson 2001).

The same phenolic compounds that act as a pro-oxidant, could act as an antioxidant agent (Cao et al. 1997), scavenging free radicals produced by sodium azide and then reducing the sodium azide mutagenic effect as observed in C. spiralis leaves aqueous extract pre- and co-treatment. Tannins, specially, are characterized by a reductive chemical structure that possesses the capacity for free radical sequestration (Silva et al. 2003). Ellagitannins and their hydrolyzed products, for example, present antimutagenic activity against sodium azide (Zahin et al. 2014, Carneiro et al. 2017), maybe because their antioxidant properties. Some alkaloids also present antioxidant activity (Ahmad et al. 2017). Thus, these metabolites could contribute to increase the antioxidant properties of $C$. spiralis extracts.

We also investigated if the difference observed between $C$. spiralis leaves or stems aqueous extracts regarding to antigenotoxic capacity was related to antioxidant activity. We observed that C. spiralis leaves present more total phenols and a higher $\mathrm{IC}_{50}$ in DPPH scavenging method than $C$. spiralis stems. A strong correlation between total phenolic content and antioxidant activity index has already been observed, with a correlation coefficient $\left(\mathrm{r}^{2}\right)$ of approximately 0.8 (Habermann et al. 2016). Moreover, leaves commonly present more total phenols and antioxidant activity index than stems (Basma et al. 2011, Mahdi-Pour et al. 2012, Habermann et al. 2016, Adebiyi et al. 2017). This way, phenolic compounds presented more in leaves than in stems of $C$. spiralis could be acting scavenging free radicals produced by sodium azide, suggesting that $C$. spiralis leaves aqueous extract possess more cell protector potential against sodium azide than the stem extract.

Despite C. spiralis leaves or stems aqueous extracts presented cytotoxic activity against $A$. cepa meristematic root cells, this extracts did not present antifungal activity against Candida spp. Similar results were previously observed. $C$. spiralis dichloromethane and methanol extracts were inactive against $C$. albicans, Cryptococcus neoformans and Aspergillus ochraceous (Habsah et al. 2000, Braga et al. 2007).

Since $C$. spiralis leaves or stems aqueous extracts presented cytotoxicity against $A$. серa meristematic cells and could enhance the sodium azide cytogenotoxicity, it is important to investigate if these extracts present the same activities against mammal cells. Empirical utilization of $C$. spiralis aqueous extracts and co-administration of herb and therapeutic drugs in popular medicine could be harmful to human health and should be avoided. However, since $C$. spiralis demonstrated to be a 
phenolic-rich raw material, it would be important to standardize phenolic extraction and separation methods thinking on pharmaceutical applications. The main bioactivities attributed to phenolic compounds are antioxidant, anti-microbial, antimutagenic, anti-angiogenic and anti-inflammatory (Sun et al. 2015). Moreover, cytotoxic effect of phenolic compound plays an important role in anticancer and antimitotic properties (Hadi et al. 2000). These possible applications turn C. spiralis and its metabolites an important target for further studies.

\section{ACKNOWLEDGMENTS}

We would like to thank Dr. Maria do Rosário Rodrigues Silva for providing Candida spp. strains and Dr. Aristônio Magalhães Teles for botanical identification. We are also grateful to Conselho Nacional de Desenvolvimento Científico e Tecnológico (CNPq) for the scholarship (PBICAF) granted to Wendel Cruvinel de Souza; and to Universidade Estadual de Goiás (UEG) for the financial support during the execution of this work (Programa de Bolsa de Incentivo à Pesquisa e Produção Científica PROBIP).

\section{REFERENCES}

ADEBIYI OE, OLAYEMI FO, NING-HUA T AND GUANGZHI Z. 2017. In vitro antioxidant activity, total phenolic and flavonoid contents of ethanol extract of stem and leaf of Grewia carpinifolia. Beni-Suef Univ J Appl Sci 6: 1014.

AHMAD H, AHMAD S, SHAH SAA, LATIF A, ALI M, KHAN FA, TAHIR MN, SHAHEEN F, WADOOD AAND AHMAD M. 2017. Antioxidant and anticholinesterase potential of diterpenoid alkaloids from Aconitum heterophyllum. Bioorg Med Chem 25: 3368-3376.

ANTUNES AS, SILVA BP AND PARENTE JP. 2000. Flavonol glycosides from leaves of Costus spiralis. Fitoterapia 71: 507-510.

BAGATINI MD, FACHINETTO JM, SILVA ACF AND TEDESCO SB. 2009. Cytotoxic effects of infusions (tea) of Solidago microglossa DC. (Asteraceae) on the cell cycle of Allium cepa. Braz J Pharmacog 19: 632-636.
BAGATINI MD, SILVA ACF AND TEDESCO SB. 2007. The use of Allium cepa test as a bioindicator of genotoxicity of medicinal plants infusions. Braz J Pharmacog 17: 444-447.

BAILÃO EFLC, DEVILLA IA, CONCEIÇÃO EC AND BORGES LL. 2015. Bioactive compounds found in Brazilian Cerrado fruits. Int J Mol Sci 16: 23760-23783.

BASMA AA, ZAKARIA Z, LATHA LY AND SASIDHARAN S. 2011. Antioxidant activity and phytochemical screening of the methanol extracts of Euphorbia hirta L. Asian Pac J Trop Med 4: 386-390.

BRAGA FG, BOUZADA MLM, FABRI RL, DE O MATOS M, MOREIRA FO, SCIO E AND COIMBRA ES. 2007. Antileishmanial and antifungal activity of plants used in traditional medicine in Brazil. J Ethnopharmacol 111: 396402.

BRITTO RM ET AL. 2011. Aqueous fraction from Costus spiralis (Jacq.) Roscoe leaf reduces contractility by impairing the calcium inward current in the mammalian myocardium. J Ethnopharmacol 138: 382-389.

CAO G, SOFIC E AND PRIOR RL. 1997. Antioxidant and prooxidant behavior of flavonoids: structure-activity relationships. Free Radic Biol Med 22: 749-760.

CARNEIRO CC, MORAES-FILHO AV, FERNANDES AS, SANTOS SC, SILVA DM AND CHEN LC. 2017. Cytotoxic and chemopreventive effects of gemin D against different mutagens using in vitro and in vivo assays. Anticancer Agents Med Chem 17: 712-718.

COSTA AF. 2001. Farmacognosia, 3rd ed., Lisboa: F. Calouste Gulbenkian, $992 \mathrm{p}$.

DI STASI LC AND HIRUMA-LIMA CA. 2002. Plantas medicinais na Amazônia e na Mata Atlântica, 2nd ed., São Paulo: Editora UNESP, 592 p.

FEDEL-MIYASATO LE, FORMAGIO AS, AUHAREK SA, KASSUYA CA, NAVARRO SD, CUNHA-LAURA AL, MONREAL AC, VIEIRA MC AND OLIVEIRA RJ. 2014. Antigenotoxic and antimutagenic effects of Schinus terebinthifolius Raddi in Allium cepa and Swiss mice: a comparative study. Genet Mol Res 13: 3411-3425.

FERGUSON LR. 2001. Role of plant polyphenols in genomic stability. Mutat Res 475: 89-111.

FISKESJO G. 1985. The Allium test as a standard in environmental monitoring. Hereditas 102: 99-112.

GALATI G AND O'BRIEN PJ. 2004. Potential toxicity of flavonoids and other dietary phenolics: significance for their chemopreventive and anticancer properties. Free Radic Biol Med 37: 287-303.

GOBBO-NETO L AND LOPES NP. 2007. Plantas medicinais: fatores de influência no conteúdo de metabólitos secundários. Quim Nova 30: 374-381.

GRUSZKA D, SZAREJKO I AND MALUSZYNSKI M. 2012. Sodium Azide as a Mutagen. In: Plant Mutation Breeding and Biotechnology. Wallingford, UK: CABI International, p. 159-166. 
HABERMANN E, IMATOMI M, PONTES FC AND GUALTIERI SC. 2016. Antioxidant activity and phenol content of extracts of bark, stems, and young and mature leaves from Blepharocalyx salicifolius (Kunth) O. Berg. Braz J Biol 76: 898-904.

HABSAH M, AMRAN M, MACKEEN MM, LAJIS NH, KIKUZAKI H, NAKATANI N, RAHMAN AA, GHAFAR AND ALI AM. 2000. Screening of Zingiberaceae extracts for antimicrobial and antioxidant activities. J Ethnopharmacol 72: 403-410.

HADI SM, ASAD SF, SINGH S AND AHMAD A. 2000. Putative mechanism for anticancer and apoptosis-inducing properties of plant-derived polyphenolic compounds. IUBMB Life 50: 167-171.

HAMMER Ø, HARPER DAT AND RYAN PD. 2001. PAST: paleontological statistics software package for education and data analysis. Palaeontol Electronica 4: 4-9.

HARTWELL LH AND WEINERT TA. 1989. Checkpoints: controls that ensure the order of cell cycle events. Science 246: 629-634.

KELLER AC, VANDEBROEK I, LIU Y, BALICK MJ, KRONENBERG F, KENNELLY EJ AND BRILLANTES AM. 2009. Costus spicatus tea failed to improve diabetic progression in C57BLKS/J db/db mice, a model of type 2 diabetes mellitus. J Ethnopharmacol 121: 248-254.

LEME DM AND MARIN-MORALES MA. 2009. Allium cepa test in environmental monitoring: a review on its application. Mutat Res 682: 71-81.

MAAS P AND MAAS H. 2015. Costaceae in Lista de Espécies da Flora do Brasil, Jardim Botânico do Rio de Janeiro.

MAHDI-POUR B, JOTHY SL, LATHA LY, CHEN Y AND SASIDHARAN S. 2012. Antioxidant activity of methanol extracts of different parts of Lantana camara. Asian Pac J Trop Biomed 2: 960-965.

MATOS FJA. 1988. Introdução à fitoquímica experimental, ed., Fortaleza: UFC, 128 p.

MATOS JMD AND MATOS MEO. 1989. Farmacognosia: curso teórico-prático, ed., Fortaleza: UFC, 245 p.

MONDIN M AND NETO AD. 2006. Citogénetica vegetal enfatizando a Família Orchidaceae. Orchidstudium 4: 2454.

PÉREZ C, FALERO A, HUNG BR, LEDÓN T AND FANDO R. 2008. Antibacterial effect of Costus spiralis leaves extract on pathogenic strains of Vibrio cholerae. Revista CENIC Ciencias Biológicas 39: 70-72.

PILLA MAC, AMOROZO MCM AND FURLAN A. 2006. Obtenção e uso das plantas medicinais no distrito de Martim Francisco, Município de Mogi-Mirim, SP, Brasil. Acta Bot Bras 20: 789-802.

RANK J AND NIELSEN MH. 1993. A modified Allium test as a tool in the screening of the genotoxicity of complex mixtures Hereditas 118: 49-53.

ROBERTO MM, JAMAL CM, MALASPINA O AND MARIN-MORALES MA. 2016. Antigenotoxicity and antimutagenicity of ethanolic extracts of Brazilian green propolis and its main botanical source determined by the Allium cepa test system. Genet Mol Biol 39: 257-269.

SAKIHAMA Y, COHEN MF, GRACE SC AND YAMASAKI H. 2002. Plant phenolic antioxidant and prooxidant activities: phenolics-induced oxidative damage mediated by metals in plants. Toxicology 177: 67-80.

SÁNCHEZ-MORENO C, LARRAURI JA AND SAURACALIXTO F. 1998. A procedure to measure the antiradical efficiency of polyphenols. J Sci Food Agric 76: 270-276.

SHI YQ, FUKAI T, SAKAGAMI H, CHANG WJ, YANG PQ, WANG FP AND NOMURA T. 2001. Cytotoxic flavonoids with isoprenoid groups from Morus mongolica. J Nat Prod 64: 181-188.

SILVA BP AND PARENTE JP. 2004. New steroidal saponins from rhizomes of Costus spiralis. Z Naturforsch C 59: 8185.

SILVA J, ERDTMANN B AND HENRIQUES JAP. 2003. Genética Toxicológica, ed., Porto Alegre: Editora Alcance, $424 \mathrm{p}$.

STURBELLE RT, PINHO DS, RESTANI RG, OLIVEIRA GR, GARCIAS GL AND MARTINO-ROTH MG. 2010. Evaluation mutagenic and antimutagenic activity of Aloe vera in Allium cepa test and micronucleus test in human binucleated lymphocytes. Braz J Pharmacog 20: 409-415.

SUDHAKAR R, GOWDA KNN AND VENU G. 2001. Mitotic abnormalities induced by silk dyeing industry effluents in the cells of Allium cepa. Cytologia 66: 235-239.

SUN Q, HEILMANN J AND KONIG B. 2015. Natural phenolic metabolites with anti-angiogenic properties - a review from the chemical point of view. Beilstein J Org Chem 11: 249-264.

TEDESCO M, KUHN AW, BOLIGON AA, LAUGHINGHOUSE IV HD, ATHAYDE ML, SILVA ACF AND TEDESCO SB. 2015. Chromatographic analysis, antiproliferative effect and genotoxicity of aqueous extracts of Citrus sinensis (L.) Osbeck on the Allium cepa L. test system. Biosci J 31: 1213-1221.

TEIXEIRA RO, CAMPAROTO ML, MANTOVANI MS AND VICENTINI VEP. 2003. Assessment of two medicinal plants, Psidium guajava L. and Achillea millefolium L. in in vivo assays. Genet Mol Biol 26: 551-555.

VIEL TA, DOMINGOS CD, MONTEIRO APS, LIMALANDMAN MTR, LAPA AJ AND SOUCCAR C. 1999. Evaluation of the antiurolithiatic activity of the extract of Costus spiralis Roscoe in rats. J Ethnopharmacol 66: $193-$ 198.

WATERMAN PG AND MOLE S. 1994. Analysis of phenolic plant metabolites, Oxford: Blackwell. Scientific Publication, $238 \mathrm{p}$.

ZAHIN M, AHMAD I, GUPTA RC AND AQIL F. 2014. Punicalagin and ellagic acid demonstrate antimutagenic activity and inhibition of benzo[a]pyrene induced DNA adducts. Biomed Res Int 2014: 1-10. 